\title{
Correlation Between Thin-Ideal Pressure and Body Appreciation Among Young Adult Women
}

\author{
Virenna T. Setiadi ${ }^{1}$ Widya Risnawaty ${ }^{1 *}$ \\ ${ }^{1}$ Departement of Psychology, Universitas Tarumanagara, Jakarta, Indonesia 11440 \\ ${ }^{*}$ Corresponding author. Email: widyar@fpsi.untar.ac.id
}

\begin{abstract}
Most people tend to have some ideal type towards something. The most common idealistic around is body ideal, such as women look up to thin-ideal type and men look up to fit and muscular-ideal type. In reality, women are more into a specific body type (thin-ideal) rather than men, therefore there's a pressure to fit into a thin-ideal type. The thin-ideal pressure come from society, especially from family, peers, \& media that may cause negative effects towards one's mental health and perspectives. There is body appreciation that might protect someone from social idealistic towards body. Therefore, this research focus on correlation between thin-ideal pressure and body appreciation among young adult women, that both variables are haven't been researched enough. There are 818 participants who participate on this research through online google form. This research use SATAQ-4 to measure thin-ideal pressure and BAS-2 to measure body appreciation. The result shows that there is a negative significant correlation between thin-ideal pressure and body appreciation in every dimension of thin-ideal pressure with $\mathrm{p}=0.00<0.05$. In this paper, will be discussed furthermore about the correlation between Body Appreciation and every dimensions of Thin-Ideal Pressure.
\end{abstract}

\section{Keywords: Body appreciation, thin-ideal pressure, young adult women}

\section{INTRODUCTION}

Previous researches can reveal the unexpected things that may affect human well-being. Studies about body image reveal that there are several things that might affect someone's in positive and negative way. Most men are accepting and satisfied with their body while women mostly struggling to accept theirs [50]. Women mostly feel unsatisfied with their bodies, tend to lose their weight, and always wanted to look thin in any circumstances [2]. Previous research found that tendencies are stable across the age [47] but may differ among 18-49 years olds [2] because of tendencies to internalize others critiques and evaluate them personally [9]. Thin and youthful-looking body are stated as the ideal body for women [20] that may cause from playing and having the Barbie doll since the young age [31]. The intensity of exposure to thin-ideal images causes the unsatisfaction on one's body [4]. Family, friends, and media play the biggest factors to pressure one's ideal body [38] and formerly found that media plays a significant role [50] that made one's normally and instantly compare their bodies $[24,30]$ even though women realize that they might've human phases that change their appearances [45]. Previous research by Suniarto et al. found that Indonesian women tend to compare their bodies with friends, actresses, and family/relatives [39] and Swami and Jafar found that men are more appreciative and accepting their bodies than women do [42]. Appearance is an important life aspect for women [27, 32] because they tend to critique one's appearances [50]. Therefore, studies show that women's body appreciation score lower than men [20,30,49]. Body appreciation, also known as positive body image [5], works as protection from appearance ideal [15]. Thin-ideal internalization [19] and low body appreciation [48] increase one's unsatisfaction towards body. Mostly playing social medias, like Instagram, affect to lower one's body appreciation [46]. Even though women could adapt on different circumstances, women still compare to other's body or appearance [13].

Thin-ideal pressure and body appreciation are two variables that've close relation with positive evaluation towards body because it may affect one's well-being. Therefore, this research focus on seeking the correlation between thin-ideal pressure and body appreciation among young adult women.

\section{BACKGROUND}

In general, thin-ideal is about subjective standard of women body that wanted by most women [44]. Thin-ideal could probably came from a cartoon that show a positive effect on a thin-looking character [19]. Women with thin-ideal, mostly aren't satisfied with their bodies [15] so that they tend to provoked by the negative impact. Idealized body image is a pressure for women to fit into a certain standard [23] because, also, women love to follow and blend into a current beauty standard [50]. By a long period, thin-ideal would get internalized and be an internalization [15] that may cause an eating disorder or any disorder that related to 
body image, body-focused anxiety, or body dissatisfaction $[21,26,33,44,7]$. Thin-ideal pressure was formed by social pressure to fit and get into a thin standard [1]. Thin-ideal pressure found from media $[3,4,7,12,25,31,44,50]$, peers, and family $[11,25,44]$ that play the biggest role in the pressure. The thin-ideal pressure made women think that thin is equal to being feminine [18]. Thin-ideal pressure is an indirect pressure that push someone to meet that standard, such as envy and doing diet or try to lose their weight [1]. That type of pressure lead someone to compare their look with others $[37,50]$ that may attack one's self esteem and well-being [36]. If the comparison being done objectively and constructive, it may give a positive impact that leads to self-evaluation, self-improvement, and enhancement [24]. The pressure focuses on women because, rather than men, women tend to do a negative comparison by judging the looks $[12,13,50]$. Women need to do a counter-argument to help them fight back the idealization about certain body type or else $[13,50]$.

There's negative body image that cause and form by nurture $[11,14]$. Media exposure and circle of peers may shift one's point of view of their appearances $[11,43]$. Negative body image is much different than positive body image [20] that positive body image is an act of love, confidence, knowing and appreciating ourselves [51]. Having a positive image towards ourselves lead into a good mental state and wellbeing [5] that form someone to appreciate their uniqueness, accept their bodies, feel pretty and happy with their bodies, having a mindful relationship with their bodies, and able to interpret an info into a constructive ones. Positive body image is the same as body appreciation [5], that means someone having a positive mindset and orientation towards their body to protect and giving a positive feedback to themselves [13]. Human also evaluated their perception towards something based on their experiences and social life that are all reciprocal $[6,28]$.

Body appreciation doesn't mean by not having a negative point of view towards body $[22,48]$ but it helps to protect them from the negative messages $[13,22]$ so that could be interpreted in a positive and constructive way. Body appreciation helps someone to feel that they're having their freedom of expressions and able to fight the social standards [16] until giving a great impact towards one's psychological well-being [10]. Body appreciation is correlated with psychological well-being $[3,48]$ to reduce one's negative perception towards body and accepting that there's no certain universal beauty standard [22]. Women with a great body appreciation able to reduce negative messages towards their bodies, selectively accepting body-related messages, and interpreting an ambiguous messages [51]. So that, one's with a great body appreciation able to respect and being kind to their bodies $[16,20]$. Having a good mindset and train ourselves to have one is a big help to develop a body appreciation [16]. Even though women will having bodyrelated phases, such as pregnancy and birth, they still want to look thin and pretty [45]. There are various activities that may improve body appreciation, such as doing yoga [17, 41]. This study focus on women in their 18-40 years old because women that age is giving attention on their appearances than men do [27] to avoid negative critiques towards their appearances [30, 43]. Young adult women easier to get the idealized pressure because they use social media a lot mot than others $[4,43,51]$.

\section{METHODS}

\subsection{Participants}

Participants of this study were 818 women from across Indonesia with range $18-40$ by age. All participants were being reached by purposive sampling method and they filled the questionnaire with their consent. Most participants were in range $18-24$ by age with $85.3 \%$. Based on their degree or last education that they took, most participants were having their high school degree with $57.7 \%$ in total. Based on their occupation status, most of them were students with $63.1 \%$. Most of them haven't married by 94.9\%. Most of participants were domicile outside of Jabodetabek (Jakarta, Bogor, Depok, Tangerang, Bekasi) with $39.5 \%$ and most of them were using social media on daily basis $(98.9 \%)$.

Table 1 Demographic characteristics of participants

\begin{tabular}{|c|c|c|}
\hline $\begin{array}{l}\text { Demographic } \\
\text { characteristics }\end{array}$ & $\mathbf{n}$ & $\%$ \\
\hline \multicolumn{3}{|l|}{ Age } \\
\hline $18-24$ & 698 & 85.3 \\
\hline $25-34$ & 114 & 13.9 \\
\hline $35-40$ & 6 & 0.7 \\
\hline \multicolumn{3}{|l|}{ Education } \\
\hline High school & 472 & 57.7 \\
\hline Associate degree & 30 & 3.7 \\
\hline Bachelor & 303 & 37 \\
\hline Master & 13 & 1.6 \\
\hline \multicolumn{3}{|l|}{ Occupation } \\
\hline Student & 516 & 63.1 \\
\hline Employee & 199 & 24.3 \\
\hline Entrepreneur & 28 & 3.4 \\
\hline Housewives & 18 & 2.2 \\
\hline Unemployed & 57 & 7 \\
\hline \multicolumn{3}{|l|}{ Marriage status } \\
\hline Not married & 776 & 94.9 \\
\hline Married & 42 & 5.1 \\
\hline \multicolumn{3}{|l|}{ Domicile } \\
\hline Jakarta & 288 & 35.2 \\
\hline Bogor & 26 & 3.2 \\
\hline Depok & 18 & 2.2 \\
\hline Tangerang & 100 & 12.2 \\
\hline Bekasi & 63 & 7.7 \\
\hline Others & 323 & 39.5 \\
\hline \multicolumn{3}{|l|}{ Most used media } \\
\hline Printed & 0 & 0 \\
\hline Electronic & 9 & 1.1 \\
\hline Social Media & 809 & 98.9 \\
\hline
\end{tabular}




\subsection{Measures}

\subsubsection{Thin-ideal pressure.}

Participants completed the Sociocultural Attitudes Towards Appearances Questionnaires-4 (SATAQ-4) [34, 35], 12item measure of related aspects of social pressure. SATAQ4 has been translated and adapted into Bahasa Indonesia by Susanto [40]. All items were rated on a 5-point scale $(1=$ Never to $5=$ Always $)$

\subsubsection{Body appreciation.}

Participants completed the Body Appreciation Scale-2 (BAS-2) [48], 10-item measure of related aspects of positive body image. BAS-2 has been translated and adapted into Bahasa Indonesia by Primarini [29]. All items weere rated on a 5 -point scale $(1=$ Never to $5=$ Always $)$.

\subsubsection{Demographics}

Participants provided their demographics details that included in the questionnaire, they are age, education, occupation, marriage status, domicile, and the most frequent media that being used by participant.

\subsubsection{Procedure}

Participants were recruited using purposive sampling by sharing the questionnaire's link online. Participant also being provided with informed consent before the main part of the questionnaire begun. All the data treated confidentially and anonymously.

\subsubsection{Statistical Analysis}

There are several statistical analyses that needed in this study, there were Spearman Correlation for the general correlation, Kruskall-Wallis H-test for analysis based on age, and Mann Whitney-U for analysis based on marital status.

\section{FINDINGS AND DISCUSSIONS}

Reliability of thin-ideal pressure family dimension has 088 Cronbach's Alphas, thin-ieal pressure peer dimension has 0.884 Cronbach's Alphas, thin-ideal pressure media dimension has 0.916 Cronbach's Alphas, and body appreciation has 0.913 (Cronbach's Alpha). Every dimension of thin-ideal pressure scale have 1 minimum score and 5 maximum score. Mean for each dimensions are vary, family dimension has $2.618(\mathrm{SD}=1.236)$, peer dimension has $2.392(\mathrm{SD}=1.102)$, and media dimension has $3.005(\mathrm{SD}=1.251)$. The differences stated that media has the biggest role on the thin-ideal pressure. Body appreciation have 1 minimum score and 5 maximum score. Mean score for body appreciation is $3.882(\mathrm{SD}=0.680)$.
This study has unnormal distribution and using Kolmogorov Smirnov Test, body appreciation has 0.069 Kolomogorov score $(\mathrm{p}=0.000<0.0 .5)$. Meanwhile thinideal pressure family dimension has 0.121 Kolomogorov score $(\mathrm{p}=0.000<0.0 .5)$, peer dimension has 0.137 Kolomogorov score $(\mathrm{p}=0.000<0.0 .5)$, and media dimension has 0.096 Kolomogorov score $(p=0.000<$ $0.0 .5)$. Therefore, spearman correlation analysis is being used. Spearman correlation show that both are having a negative significant correlation. Family dimension has negative correlation with body appreciation with $\mathrm{r}(818)=$ $0.288, \mathrm{p}=0.000<0.5$. Peer dimension has negative correlation with body appreciation with $\mathrm{r}(818)=-0.253$, $\mathrm{p}$ $=0.000<0.5$. Media dimension has negative correlation with body appreciation with $\mathrm{r}(818)=-0.355, \mathrm{p}=0.000<$ 0.5 .

Table 2 Spearman correlation between thin-ideal pressure and body appreciation

\begin{tabular}{lcc}
\hline Thin-Ideal & \multicolumn{2}{c}{ Body Appreciation } \\
Pressure & r & P \\
\hline Family & $-0.288^{* *}$ & 0.000 \\
Peers & $-0.253^{* *}$ & 0.000 \\
Media & $-0.355^{* *}$ & 0.000 \\
\hline$* *$ Correlation is significant at the 0.01 level (2-tailed)
\end{tabular}

To prove the significancy between other optional measurement, analysing thin-ideal pressure score based on age are using Kruskal Wallis $\mathrm{H}$ Test and there's no significant differences with $\mathrm{H}(2)<9.21, \mathrm{p}>0.005$. Meanwhile, body appreciation score based on age has significant differences with $\mathrm{H}(2)>9.21, \mathrm{p}<0.005$. Mann Whitney- $U$ analysis is being used to find significancy difference on each variables based on marriage status. Both, thin-ideal pressure and body appreciation scores aren't significant $(\mathrm{p}>0.05)$.

Table 3 Thin-ideal pressure (T-I P) and body appreciation by age

\begin{tabular}{lccc}
\hline Variable & Age & $\begin{array}{c}\text { Mean } \\
\text { Rank }\end{array}$ & P \\
\hline \multirow{3}{*}{ T-I P Family } & $18-24$ & 411.18 & \\
& $25-34$ & 402.55 & 0.753 \\
& $35-40$ & 346.17 & \\
T-I P Peers & $18-24$ & 408.41 & \\
& $25-34$ & 419.50 & 0.722 \\
& $35-40$ & 346.50 & \\
T-I P Media & $18-24$ & 414.91 & \\
& $25-34$ & 386.99 & 0.055 \\
Body & $35-40$ & 208.00 & \\
Appreciation & $18-24$ & 398.50 & \\
& $25-34$ & 478.89 & 0.003 \\
\hline
\end{tabular}


Table 4 Thin-ideal pressure (T-I P) and body appreciation by marriage status

\begin{tabular}{|c|c|c|c|}
\hline Variable & $\begin{array}{c}\text { Marriage } \\
\text { Status }\end{array}$ & $\begin{array}{l}\text { Mean } \\
\text { Rank }\end{array}$ & $\mathbf{P}$ \\
\hline \multirow[t]{2}{*}{ T-I P Family } & $\begin{array}{l}\text { Not } \\
\text { married }\end{array}$ & 409.63 & \multirow[t]{2}{*}{0.948} \\
\hline & Married & 407.18 & \\
\hline \multirow[t]{2}{*}{ T-I P Peers } & $\begin{array}{l}\text { Not } \\
\text { married }\end{array}$ & 407.85 & \multirow[t]{2}{*}{0.387} \\
\hline & Married & 440.06 & \\
\hline \multirow[t]{2}{*}{ T-I P Media } & $\begin{array}{l}\text { Not } \\
\text { married }\end{array}$ & 410.00 & \multirow[t]{2}{*}{0.795} \\
\hline & Married & 400.32 & \\
\hline \multirow{2}{*}{$\begin{array}{l}\text { Body } \\
\text { Appreciation }\end{array}$} & Not & 405.53 & \multirow{2}{*}{0.039} \\
\hline & Married & 482.80 & \\
\hline
\end{tabular}

Social media in media dimension play the biggest role in thin-ideal pressure, it may be caused by the pandemic that forced people to stay at home so their entertainment source, mostly come from social media. There's no significant differences in thin-ideal pressure based on age that may be caused by a large interval of age in this study. Therefore, it's needed to look into more specific ages or developmental stages.

\section{CONCLUSIONS}

Based on all the data, this research has not normal distribution with negative correlation between thin-ideal pressure and body appreciation among young adult women. Every dimension in thin-ideal pressure have negative correlation to body appreciation, with significant correlation with age grouping. This study aligned with Tiggemann \& McCourt's research about body appreciation throughout women life span [47] that women's body appreciation arises throughout life span. Future studies may focus on smaller range or varies of participants, so that it can focused to look depth into certain groups. Qualitative study also required to solve and find direct personal problems. For general public, they also need to bring a positive social media environment, such as commenting and/or giving positive feedbacks rather than judging or hate speech.

\section{REFERENCES}

[1] A. L. Ahern, K. M. Bennett, M. Kelly, M. M. Hetherington, A qualitative exploration of young women's attitudes towards the thin ideal, Journal of Health Psychology, 16(1), 70-79, 2011, https://doi.org/10.1177/1359105310367690

[2] M. Ålgars, P. Santtila, M. Varjonen, K. Witting, A. Johansson, P. Jern, N. K Sandnabba, The adult body: How age, gender, and body mass index are related to body image, Journal of Aging and Health, 21(8), 1112 1132, 2009, https://doi.org/10.1177/0898264309348023

[3] R. Andrew, M. Tiggemann, L. Clark, Predicting body appreciation in young women: An integrated model of positive body image, Body Image, 18, 34-42, 2016, https://doi.org/10.1016/j.bodyim.2016.04.003

[4] F. Anixiadis, E. H. Wertheim, R. Rodgers, B. Caruana, Effects of thin-ideal instagram images: The roles of appearance comparisons, internalization of the thin ideal and critical media processing, Body Image, 31, 181-190, 2019, https://doi.org/10.1016/j.bodyim. 2019. 10.005

[5] L. Avalos, T. L. Tylka, N. Wood-Barcalow, The Body Appreciation Scale: Development and psychometric evaluation Body Image, 2(3), 285- 297, 2005, https://doi.org/10.1016/j.bodyim.2005.06.002

[6] A. Bandura, Social Cognitive Theory of Mass Communication Media Psychology, 3(3), 265-299, 2001, https://doi.org/10.1207/S1532785XMEP0303_03

[7] A. Brown, H. Dittmar, Think "thin" and feel bad: The role of appearance schema activation, attention level, and thin-ideal internalization for young women's responses to ultra-thin media ideals, Journal of Social and Clinical Psychology, 24(8), 1088-1113, 2005, https://doi.org/ 10.1521/jscp.2005.24.8.1088

[8] A. Brown, T. F. Cash, P. J. Mikulka, Attitudinal Body-Image Assessment: Factor Analysis of the BodySelf Relations Questionnaire, Journal of Personality Assessment, 55(1-2), 135-144, 1990, https://doi.org/ $10.1080 / 00223891.1990 .9674053$

[9] R. S. Caffarella, S. K. Olson, Psychosocial development of women: A critical review of the literature, ADULT EDUCATION QUARTERLY, 43(3), 125-151, 1993.

[10] T. F. Cash, E. C. Fleming, The impact of body image experiences: Development of the body image quality of life inventory, International Journal of Eating Disorders, 31(4), 455-460, 2002, https://doi.org/10. 1002/eat.10033

[11] L. Clark, M. Tiggemann, Sociocultural and Individual Psychological Predictors of Body Image in Young Girls: A Prospective Study, Developmental Psychology, 44(4), 1124-1134, 2008, https://doi.org/ 10.1037/0012- 1649.44.4.1124

[12] H. Dittmar, E. Halliwell, E. Stirling, Understanding the impact of thin media models on women's bodyfocused affect: the roles of thin-ideal internalization and 
weight-related self-discrepancy activation in experimental exposure effects, Journal of Social and Clinical Psychology, 28(1), 43-72, 2009, https://doi. org/10.1521/jscp.2009.28.1.43

[13] R. Engeln-Maddox, Cognitive responses to idealized media images of women: The relationship of social comparison and critical processing to body image disturbance in college women, Journal of Social and Clinical Psychology, 24(8), 1114-1138, 2005, https:// doi.org/10.1521/jscp.2005.24.8.1114

[14] A. Feingold, R. Mazzella, Gender differences in body image are increasing, Psychological Science, 9(3), 190-195, 1998, https://doi.org/10.1111/1467-9280. 00036

[15] E. Halliwell, The impact of thin idealized media images on body satisfaction: Does body appreciation protect women from negative effects? Body Image, 10(4), 509-514, 2013, https://doi.org/10.1016/j.bodyim. 2013.07.004

[16] E. Halliwell, Future directions for positive body image research, Body Image, 14, 177-189, 2015, https://doi.org/10.1016/j.bodyim.2015.03.003

[17] E. Halliwell, K. Dawson, S. Burkey, A randomized experimental evaluation of a yoga-based body image intervention, Body Image, 28, 119- 127, 2019, https://doi.org/10.1016/j.bodyim.2018.12.005

[18] B. Harper, M. Tiggemann, The effect of thin ideal media images on women's self-objectification, mood, and body image, Sex Roles, 58(9-10), 649-657, 2008, https://doi.org/10.1007/s11199-007-9379-x

[19] J. A. Harriger, K. N. Serier, M. Luedke, S. Robertson, A. Bojorquez, Appearance-related themes in children's animated movies released between 2004 and 2016: A content analysis, Body Image, 26, 78-82, 2018, https://doi.org/10.1016/j.bodyim.2018.06.004

[20] J. He, S. Sun, H. F. Zickgraf, Z. Lin, X. Fan, Metaanalysis of gender differences in body appreciation, Body Image, 33, 90-100, 2020, https://doi.org/10. 1016/j.bodyim.2020.02.011

[21] S. Hoffmann, P. Warschburger, Prospective relations among internalization of beauty ideals, body image concerns, and body change behaviors: Considering thinness and muscularity, Body Image, 28, 159-167, 2019, https://doi.org/10.1016/j.bodyim.2019. 01.011

[22] K. J. Homan, T. L. Tylka, Self-compassion moderates body comparison and appearance self-worth's inverse relationships with body appreciation, Body Image, 15, 1-7, 2015, https://doi.org/10.1016/j.bodyim. 2015.04.007

[23] C. Knauss, S. J. Paxton, F. D. Alsaker, Relationships amongst body dissatisfaction, internalisation of the media body ideal and perceived pressure from media in adolescent girls and boys, Body Image, 4(4), 353-360, 2007, https://doi.org/10.1016/j.bodyim.2007.06.007

[24] N. Lewis, Experiences of upward social comparison in entertainment contexts: Emotions, state self-esteem, and enjoyment, Social Science Journal, 2019, https://doi.org/10.1016/j.soscij.2019.04.011

[25] S. A. McLean, S. J. Paxton, E. H. Werthei, Does Media Literacy Mitigate Risk for Reduced Body Satisfaction Following Exposure to Thin- Ideal Media? Journal of Youth and Adolescence, 45(8), 1678-1695, 2016, https://doi.org/10.1007/s10964-016-0440-3

[26] C. Morton, T. A. Mooney, L. L. Lozano, E. A Adams, H. M. Makriyianis, M. Liss, Psychological inflexibility moderates the relationship between thinideal internalization and disordered eating, Eating Behaviors, 36, 101345, 2020, https://doi.org/10.1016/j. eatbeh.2019.101345

[27] P. Öberg, L. Tornstam, Body images among men and women of different ages, Ageing and Society, 19(5), 629-644, 1999, https://doi.org/10.1017/ S0144686X99007394

[28] L. A. Pervin, O. P. John, Handbook of personality: Theory and research (2nd ed.), Guilford Press, 1999.

[29] B. A. Primarini, Perbedaan Tingkat Body Image pada Remaja Akhir Bertato di Yogyakarta Ditinjau dari Jenis Kelamin (Issue 3), 2019, https://doi.org/10. 1590/S1413-81232013001200017

[30] H. L. Quittkat, A. S. Hartmann, R. Düsing, U. Buhlmann, S. Vocks, Body Dissatisfaction, Importance of Appearance, and Body Appreciation in Men and Women Over the Lifespan, Frontiers in Psychiatry, 10(December), 1-12, 2019, https://doi.org/10.3389/ fpsyt.2019.00864

[31] K. Rice, I. Prichard, M. Tiggemann, A. Slater, Exposure to Barbie: Effects on thin-ideal internalisation, body esteem, and body dissatisfaction among young girls, Body Image, 19, 142-149, 2016, https://doi.org/ 10.1016/j.bodyim.2016.09.005

[32] J. C. Rosen, P. Orosan, J. Reiter, Cognitive behavior therapy for negative body image in obese women, 
Behavior Therapy, 26(1), 25-42, 1995. https://doi.org/ 10.1016/S0005-7894(05)80081-4

[33] L. M. Schaefer, N. L. Burke, J. K. Thompson, Thinideal internalization: How much is too much? Eating and Weight Disorders, 24(5), 933-937, 2019, https://doi.org/10.1007/s40519-018-0498-х

[34] L. M. Schaefer, N. L. Burke, K. J. Thompson, R. F. Dedrick, L. J. Heinberg, R. M. Cologero, A. M. BardoneCone, M. K. Higgins, D. A. Frederick, M. Kelly, D. A. Anderson, K. Schaumberg, A. Nerini, C. Stefanile, H. Dittmar, E. Clark, Z. Adams, S. Macwana, K. L. Klump, ..., V. Swami, Westminster Research toward appearance questionnaire-4 (SATAQ-4), Psychological Assessmnet, 27(1), 54-67, 2015.

[35] L. M. Schaefer, J. A. Harriger, L. J. Heinberg, T. Soderberg, J. K. Thompson, Development and validation of the sociocultural attitudes towards appearance questionnaire-4-revised (SATAQ-4R), International Journal of Eating Disorders, 50(2), 104-117, 2017, https://doi.org/10.1002/eat.22590

[36] D. Schmuck, K. Karsay, J. Matthes, A. Stevic, "Looking Up and Feeling Down". The influence of mobile social networking site use on upward social comparison, self-esteem, and well-being of adult smartphone users, Telematics and Informatics, 42(February), 101240, 2019, https://doi.org/10.1016/ j.tele.2019.101240

[37] A. Slater, N. Cole, J. Fardouly, The effect of exposure to parodies of thin-ideal images on young women's body image and mood, Body Image , 29, 82-89, 2019, https://doi.org/10.1016/j.bodyim.2019.03.001

[38] E. Stice, D. Spangler, W. S. Agras, Exposure to media-portrayed thin- ideal images adversely affects vulnerable girls: A longitudinal experiment, Journal of Social and Clinical Psychology, 20(3), 270-288, 2001, https://doi.org/10.1521/jscp.20.3.270.22309

[39] L. Sunartio, M. E. Sukamto, K. Dianovinina, Social Comparison dan Body Dissatisfaction pada Wanita Dewasa Awal. Humanitas, 9(2), 2012.

[40] V. V. M. Susanto, D. N. Wirawan, I. P. A. Griadhi, Predictor of muscle dysmorphia among members of fitness centers in Denpasar City, Bali, Indonesia. 8(1), 4-10, 2020, https://doi.org/10.15562/phpma.v8i1.234

[41] V. Swami, D. Barron, R. Hari, S. Grover, L. Smith, A. Furnham, The Nature of Positive Body Image: Examining Associations Between Nature Exposure, Self-Compassion, Functionality Appreciation, and Body
Appreciation, Ecopsychology, 11(4), 243-253, 2019, https://doi.org/10.1089/eco.2019.0019

[42] V. Swami, J. L. Jaafar, Factor structure of the Body Appreciation Scale among Indonesian women and men: Further evidence of a two-factor solution in a nonWestern population, Body Image, 9(4), 539-542, 2012, https://doi.org/10.1016/j.bodyim.2012.06.002

[43] M. B. Tamburrino, Body Image: A Handbook of Theory, Research, and Clinical Practice, In JAMA: The Journal of the American Medical Association, 289(14), 2003, https://doi.org/10.1001/jama.289.14.1861

[44] J. K. Thompson, E. Stice, Thin-ideal internalization: Mounting evidence for a new risk factor for body-image disturbance and eating pathology, Current Directions in Psychological Science, 10(5), 181-183, 2001, https:// doi.org/10.1111/1467-8721.00144

[45] M. Tiggemann, Body image across the adult life span: Stability and change, Body Image, 1(1), 29-41, 2004, https://doi.org/10.1016/S1740- 1445(03)00002-0

[46] M. Tiggemann, I. Anderberg, Z. Brown, \#Loveyourbody: The effect of body positive Instagram captions on women's body image, Body Image, 33, 129136, 2020, https://doi.org/10.1016/j.bodyim.2020.02. 015

[47] M. Tiggemann, A. McCourt, Body appreciation in adult women: Relationships with age and body satisfaction, Body Image, 10(4), 624-627, 2013, https://doi.org/10.1016/j.bodyim.2013.07.003

[48] T. L. Tylka, N. L. Wood-Barcalow, The body appreciation scale-2: Item refinement and psychometric evaluation, Body Image, 12(1), 53-67, 2015, https:// doi.org/10.1016/j.bodyim.2014.09.006

[49] B. Verplanken, R. Velsvik, Habitual negative body image thinking as psychological risk factor in adolescents, Body Image , 5(2), 133-140, 2008, https:// doi.org/10.1016/j.bodyim.2007.11.001

[50] A. A. Watson, S. K. Murnen, K. College, Gender differences in responses to thin, athletic, and hypermuscular idealized bodies, Body Image, 30, 1-9, 2019, https://doi.org/10.1016/j.bodyim.2019.03.010

[51] N. L. Wood-Barcalow, T. L. Tylka, C. L. AugustusHorvath, "But I Like My Body": Positive body image characteristics and a holistic model for young-adult women, Body Image, 7(2), 106-116, 2010, https:// doi.org/10.1016/j.bodyim.2010.01.001 